\title{
Cúchulain in the General Post Office: Gaelic revival, Irish rising
}

\author{
Sir John Rhŷs Memorial Lecture \\ read 22 March 2016 \\ JOEP LEERSSEN \\ University of Amsterdam
}

\begin{abstract}
This article looks at the importance of the Gaelic language for the development of Irish nationalism in the decades leading up to, and following the Easter Rising of 1916. This importance was mainly symbolical: the Irish language was used mainly by revivalist activists, in a restricted number of functional registers, and largely as an enabling platform of other consciousness-raising activities. It is suggested, however, that such a symbolical instrumentalisation is by no means inconsequential and should be analysed as an important feature of cultural nationalism, not only in Irish history.
\end{abstract}

Keywords: Irish language, cultural nationalism, Irish nationalism, Irish history, language revival

\section{BACK AND FORTH ACROSS THE TIME-FRAME: FILIATIONS AND AFFILIATIONS}

In 1914, James Joyce published his story collection Dubliners. The closing story, 'The Dead', evokes a post-Christmas party in early 1904. In the course of the evening, the young journalist Gabriel Conroy sees his plans for the future overwhelmed by the shadow of a resurrected past: his wife's resurging memories of a dead childhood romance in Galway. Part of the festive gathering is a Gaelic language activist, Miss Ivors, who denounces Conroy's Edwardian cosmopolitanism and urges him to turn to his own country instead.

- $\mathrm{O}, \mathrm{Mr}$ Conroy, will you come for an excursion to the Aran Isles this summer? We're going to stay there a whole month. It will be splendid out in the Atlantic. You ought to come....

- Well, we usually go to France or Belgium or perhaps Germany, said Gabriel awkwardly. 
- And why do you go to France and Belgium, said Miss Ivors, instead of visiting your own land?

- Well, said Gabriel, it's partly to keep in touch with the languages and partly for a change.

- And haven’t you your own language to keep in touch with - Irish? asked Miss Ivors.

- Well, said Gabriel, if it comes to that, you know, Irish is not my language.

Their neighbours had turned to listen to the cross-examination. Gabriel glanced right and left nervously and tried to keep his good humour under the ordeal which was making a blush invade his forehead.

- And haven't you your own land to visit, continued Miss Ivors, that you know nothing of, your own people, and your own country?

(Joyce [1914 (1956), 186-7)

With consummate period feel, Joyce is referring to a type of cultural revivalism, distinctly 'pre-War' by the time the story came out, but much in vogue around 1904. The Gaelic League journal An Claidheamh Soluis had in 1902 carried advertisements for the type of Westward tourism that Miss Ivors is referring to (figure 1). In its evocation of the West of Ireland and Galway, the publicity drive had deployed precisely that contrastive discourse of dormancy and revival which also suffuses 'The Dead'. The ad's opening header quotes a ballad by the revered Romantic poet, Thomas Davis. His ballad 'The West's Asleep'-which, as any revivalist and ballad-singing Dubliner would have known - culminates in the rousing final lines 'let England quake! The West's awake!' Such a wake-up call is what the 'Invasion of Galway' hopes to deliver, with its declaration of 'War on Anglicisation'.'

Much had changed between the date at which 'The Dead' 1904, is set, and the date of writing, 1914. From the perspective of 1914, Joyce is also presenting this traditionalist revivalism as a form of cultural necromancy, calling up the ghosts of the dead, and as a nativist, introspective form of anti-cosmopolitanism. ${ }^{2}$ Unlike the protagonist, Gabriel Conroy, Joyce abandoned Dublin and its obsession with the West and with the unresolved past. His personal odyssey took him to Trieste, Zurich and Paris,

\footnotetext{
${ }^{1}$ On the idealisation of the Gaelic-speaking Western districts in the revivalist programme, see Ó Torna (2005), who also refers to the excursion advertisement discussed here. For the reproduction, I am obliged to the staff of the Long Room Hub and the Berkeley Library, Trinity College Dublin.

${ }^{2}$ I think the internal and contextual evidence for such a reading is overwhelming, given the narrative economy both of the individual story and its place in the general tenor of Dubliners as a whole (as well as later references to the Conroy character in Ulysses), and in the light of Joyce's own life choices between 1904 and 1914; I confess myself unconvinced by readings which represent the 'journey Westward' as a positive and optimistic commitment to femininity and Irish rootedness.
} 


\section{Conmradh) na Gaedlbilge, (raobb) Colmcbille.}

An EXCURSION, of the

IRISH SPEAKING GALWAY. :-

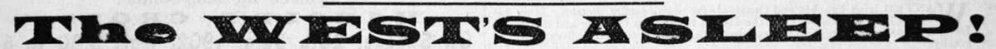

But if ever in this world the West is going to be roused up out of its slumbers, it will be when

\section{The GREAT INVASION OF GALWAY COMES OFF \\ On SUNDAY, JULY 27th, NEXT. \\ Not from Dublin alone, but every Town and Village throughout the West will send its Representative, till from far and wide through Connaught the}

\section{DECLARE WAR ON ANGLICISATION !}

This is to be no ordinary Excursion for pleasure only. Opportunities such as this can come but once or twice a year at most. The great Irish centres of the West will be Irish centres no more after a few years unless the full force of the Irish Revival is brought to bear upon them whenmore apter a ferw years, and all earnest Gaels are exhorted to make the memory of this day, and the influence of its proceedings, such as will never be lost or forgotten in the Capital of Connaught.

VERY REV. DR. MacCORMACK, Lord Bishop of Galway.

Dr. DOUGLAS HYDE. Rev. Dr. O'HICKEY. Rev. Fr. KAVANAGH, O.S.F. Rev Fr. O'DONOVAN. Mr. JOHN MacNEILL.

THE MEMBERS OF THE LEAGUE EXECUTIVE.

THE EDITORS OF "An claróati,", THE "ALL IRELAND REVIEW," THE EDT "THE LEADER," “THE UNITED IRISHMAN."

MISS MAUD GONNE. LADY GREGORY. Mr. EDWARD MARTYN. Mr. SEUMAS MacMANUS. Mr. W. B. YEATS.
And all LEADING GAELIC LEAGUERS THROUGHOUT IRELAND have And all LEADING GAEited to take part in the proceedings.

The fine Band of the Catholic Boys' Brigade, Church St., will accompany the Excursion.

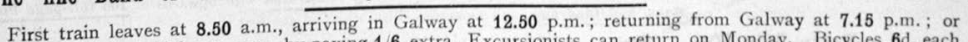
First train leaves at 8.50 a.m., arriving in $1 / 6$ extra, Excursionists can return on Monday. Bicycles 6 d. each by Night Mail at 12.0 p.m.;

(return fare), at owner's risk. day's Proceedings, List of Hotels, \&c., will be distributed free on Railway Platform, on the morning of Excursion.

The Tickets, price only $4 \mathbf{s}$. Return, can be had at the Colmcille Branch of The Tickets, price only 4 the Gaelic League, 5 Blackhall Street, Dublin.

Figure 1. Advertisement for Gaelic League excursion to Galway (An Claidheamh Soluis, 19 July 1902).

where eventually he fought Anglicisation, not by learning Irish but by writing Finnegans Wake (1939).

A few years before Finnegans Wake appeared, a statue of the dying mythical hero Cúchulain was dedicated in Dublin's General Post Office - commemorative site of the Easter Rising - by the head of the Irish government, Éamon de Valera (figure 2).

That was in 1935. Under a new constitution that came into effect two years later, in 1937, de Valera's office as head of government came to be designated by the Gaelic term Taoiseach, a word from the same archaic warrior society that the hero Cúchulain belonged to, roughly the equivalent of the English word 'chieftain'. The same constitution stipulated that Gaelic was the state's national language, with English enjoying recognition as the state's second official language. 


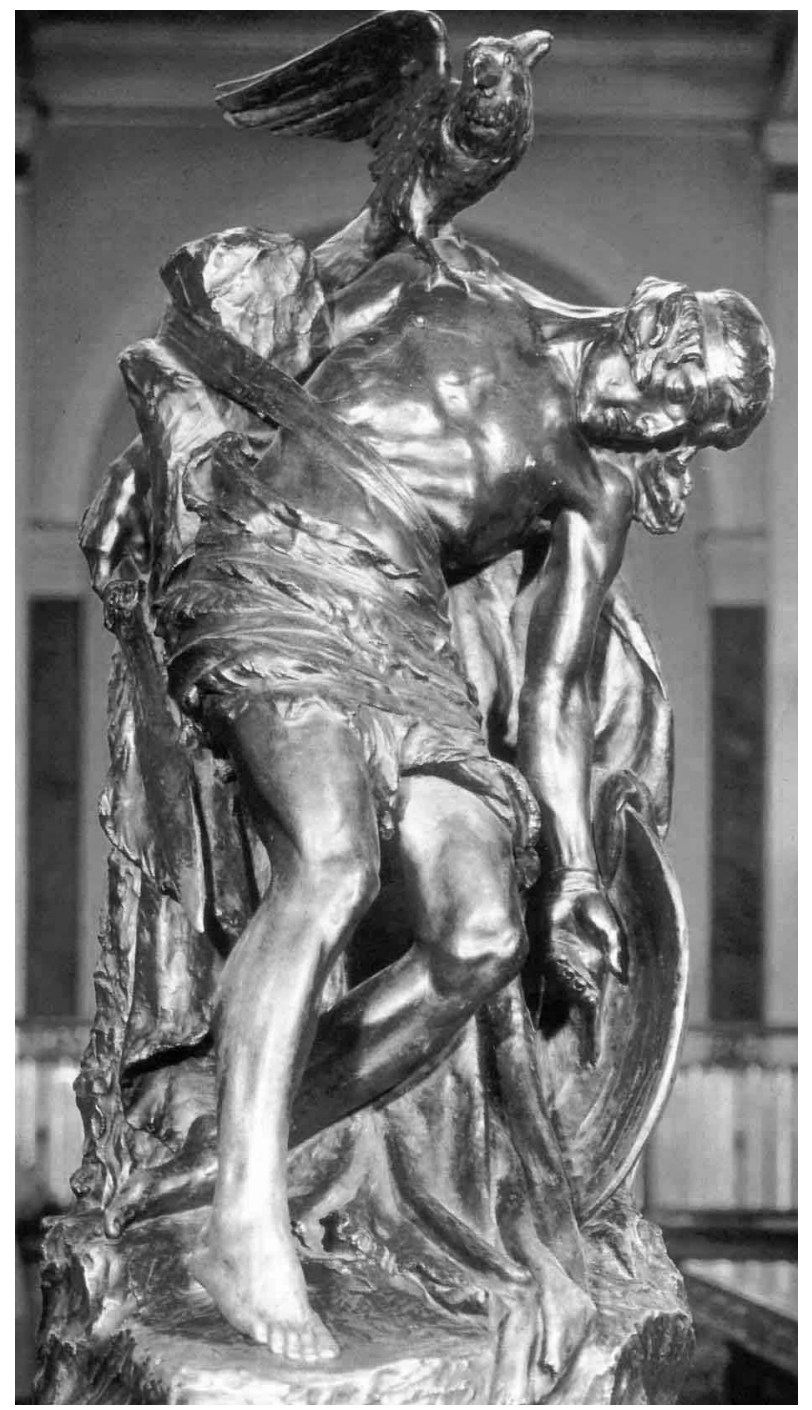

Figure 2. Oliver Sheppard, 'The Dying Cúchulain' (1911), given official placement in Dublin’s General Post Office, 1935.

That distinction between the national language, Gaelic (henceforth increasingly called 'Irish'3), and a subsidiary official language, English, dated back to an earlier

${ }^{3}$ The choice between 'Gaelic' and 'Irish' carries subliminal, bothersome connotations, which I wish to dispel by clarifying my preference: I call the language Gaelic, certainly when referring to its pre-1922 position, as offering the closer analogue to its self-appellation Gaedhilge/Gaeilge, and in order to avoid confusion with the word 'Irish', which I apply specifically to the country's geography, society and politics. The two semantic spheres overlap when the language's constitutional status and the state's language policies (post-1922) are at issue, in which case I occasionally use 'Irish' to reflect the corresponding usage in the sources. Irish-Gaelic is cumbersome and only useful when juxtaposing the language with its Scottish-Gaelic sibling. 
constitution: the one adopted in 1922 by the Irish Free State. ${ }^{4}$ In turn, that 1922 constitution was itself the consolidation of a de facto independence declared by the country's first self-styled, secessionist parliament (calling itself Dáil Éireann or 'The Assembly of Ireland') in 1919. This 1919 declaration of independence was issued in three languages, in an obvious symbolical pecking order: Gaelic, as the main and official version, followed by French (the language of international diplomacy and of the Paris Peace Conference at the time) and finally English (the language of American president Woodrow Wilson, whose support for Irish self-determination was being sought). ${ }^{5}$ The 'war on Anglicisation' was still on.

Ultimately (to telescope yet further back in the 1935-1922-1919 series), the 1919 declaration of independence invoked the proclamation of the Irish Republic issued by Patrick Pearse and his co-signatories during the Easter Rising of 1916. Pearse was celebrated in the 1935 commemoration as the very reincarnation of Cúchulain: the man who, as Yeats poetically phrased it, had 'summoned Cúchulain to his side' in the GPO, had combined cultural revivalism and separatist nationalism, whose vision of Ireland informed what the constitution of 1937 sought to consolidate: 'Ireland as we of today would surely have her: not free merely, but Gaelic as well; not Gaelic merely, but free as well. ${ }^{6}$

Yoking Cúchulain and Pearse, and using the word Taoiseach to associate modern prime ministers with ancient chieftains, is a type of anachronism which used to be debunked as an 'invention of tradition'. Nowadays, the emphasis is more on understanding our ways of drawing on the past than on mere, smug debunking, and the discipline of Memory Studies uses the more neutral concept of affiliation. Unlike straightforward filiation, which denotes a transmission of identity downwards in time along a descending succession of generations - an example would be the filiation of declaration/proclamation/constitutions outlined above, reaching from 1916 to 1937 affiliation denotes a process working backward in history, selecting historical antecedents from the past in order to provide symbolical identity-anchors in the present, searching for historical auspices under which one wishes to place oneself. ${ }^{7}$

In what follows, I want to juxtapose these notions of filiation and affiliation. As my criss-crossings of the period 1904-39 indicate, filiation and affiliation, the way history moves to the future and looks to the past, usually work in tandem. While the

\footnotetext{
${ }^{4}$ This principle of subsidiary bilingualism had been elaborated in some judicial rulings in the meantime. Cf. Mac Giolla Chríost (2005: 119-120) on the jurisprudence and the influence of Chief Justice O'Kennedy in 1934.

${ }^{5}$ The three texts are given in Macardle (1937), who also stresses their underlying diplomatic importance, and concurrent efforts to obtain American and international support for Irish independence.

${ }^{6}$ The slogan was uttered by Pearse at the graveside oration of O'Donovan Rossa (1 August 1915).

${ }^{7}$ I adopt this conceptual distinction from Rigney (2012).
} 
modern state affiliated itself to a primordial authentic Gaelic antiquity (say: Cúchulain) it stood in a direct line of filiation to the Miss Ivors generation of Gaelic Leaguers that had made this Gaelicism such a powerful nation-building tool. The habit of a Gaelic-focused historicist affiliation came to de Valera and his generation in a direct paper trail from Pearse himself and Pearse's mentor, Douglas Hyde, founder of the Gaelic League. Indeed, the state that in 1937 gave itself a new constitution also chose that ancient father-figure, Douglas Hyde, then 78 years old, for its first president. Hyde, a gentleman-scholar, amateur folklorist and maître à penser to an entire generation of cultural revivalists, had formulated a culture-revivalist programme, hinging around the Gaelic language, which was to prove, if not a sufficient, then at least a necessary condition for the independence bid of 1916. Those revivalists inspired by Hyde, who in 1903 declared a 'War on Anglicisation', saw it as their task to redeem modern Ireland from its dreary provincialism by reconnecting it to an ancient, almost-vanished or threatened tradition, and to restore its declining language.

\section{CULTURAL ACTIVISTS AND CULTURAL NATIONALISM}

Who were these revivalists? They do not represent an easily labeled stratum or cohort such as 'elites', 'proletarians', 'intellectuals', 'avant-garde', or that eternal Woozle, a 'rising middle class' - if anything, the revivalism platform provided an uneasily negotiated meeting ground between all of these (the list of invited speakers for the 1902 Galway excursion provides a telling illustration). Nor can they be pigeon-holed into the threadbare categories of native vs Anglo-Irish; both Gaelic-speaking rustics and affluent toffs were under- rather than overrepresented in their ranks, which largely consisted of suburban city-dwellers ranging from white-collar workers to the comfortable middle classes (think Miss Ivors) ${ }^{8}$ Nor, again, does the category of religion provide a specific profile: again, the revivalist movement was characterised by the very awkwardness of its denominational heterogeneity, priests drawing as much Protestant suspicion or secularist animus as they wielded Catholic clout. ${ }^{9}$

\footnotetext{
${ }^{8}$ Roy Foster's Vivid Faces (2015), also relied upon in these pages for a good deal of factual information, is an inspiring approach to the revivalists as a generational cohort (as per Karl Mannheim's concept of the 'generation'). I share Foster's unease with other types of social classification, which is reflected in his use of class identifiers ranging from haute bourgeoise, (66), through various gradations of middle-class Catholics (including also a 'Dublin Catholic haute bourgeoisie) and 'middle- and upper-class Protestants' (71-72), to a 'rural bourgeoisie' (either 'well-off', 117, or petite, 169), and even a Lumpenbourgeoisie (99). ${ }^{9} \mathrm{The}$ prominence of priests in public life was par for the course in early-20th-century Ireland, as was the intransigence of ultramontanism and the generalised habit of interdenominational suspicion; such factors are background conditions of the historical facts rather than providing an analysis of them. Indeed, the salient role played by priests is more interesting in a quite different respect than that of generic denominational politics. Here, as elsewhere in Europe, priests were in the unique position that
} 
The revivalists were a motley crew and were indeed identified as such ('wherever motley is worn') by Yeats in his poem 'Easter 1916'. I would tentatively characterise them as something between a mass movement and a rarefied intellectual elite, as 'cultural generators' (with Bourdieu's idea of cultural production in mind, as well as the German/Dutch concept of Kulturträger / cultuurdragers, 'cultural carriers'). Cultural generators do not fit any particular social stratum, ${ }^{10}$ but, whatever their social, religious or ethnic background, combine cultural production and its public dissemination through their sociability and activism. This is what I have analysed elsewhere as the 'cultivation of culture': folklore-collecting, literary creation, nationally themed visual arts and music, the retrieval of ancient texts and tales, and the associational sociability that turns these pursuits from private interests into social mobilisation. I shall here concentrate on, but not limit myself to, the position of the Gaelic language in this activist palette of the 'cultivation of culture' (Leerssen 2006).

The cultivation of culture followed a trajectory of increasing political activation in the years leading up to 1916. Pearse's Ireland 'not free merely, but Gaelic as well; not Gaelic merely, but free as well', had been heralded by the cultural 'war on Anglicisation' proclaimed in 1902, which in turn took its cue from Douglas Hyde's lecture 'On the Necessity for De-Anglicising Ireland' of 1893 (another filiation). Hyde's most important impact lies in the fact that that lecture, and the Gaelic League whose foundation was inspired by it, mobilised a new presence on the Irish political scene: the cultural generators; and their rallying cry was the Irish language.

These revivalists, mobilised by Hyde's lecture - and here, as in other respects, I follow John Hutchinson's benchmark analysis (1987) — were the third wave of cultural nationalism in Ireland. The first had occurred in the decades after Macpherson's Ossian, in the late 18th century. The second in the Romantic decades after 1820.

they were highly educated but in daily, intimate touch with the vernacular-speaking rustic population. As such, their role is no different from Anglican clergymen in Wales (Thomas Price) or indeed in Ireland (witness Hyde's own background), or Lutheran pastors in Iceland, Finland, Latvia and Estonia, or Catholic priests in Lithuania and Flanders. They all played an important role as conduits between vernacular-popular culture and its national cultivation by intellectuals. A similar intermediary position between vernacular culture and the world of learning was played by country doctors, like Lönnrot in Finland or Basanavičius in Lithuania and Bulgaria.

${ }^{10}$ They consist of activists in associations and organisations, intellectuals, scholars and academics, writers, creative and performing artists. The meaning is close to that of an intelligentsia, invoked by John Hutchinson (1987), or the French idea of the intellectuel (although it does not necessarily presuppose the benefit of higher education; cf. Golding 1993). The point bears repeating that the idea of the cultural producer cannot be subsumed under the ingrained heuristic opposition between elites and masses: they straddle the two, and establish a conduit between them. 
I would call these waves 'antiquarian' and 'philological-romantic', respectively, ${ }^{11}$ and as such they correspond to larger European patterns. ${ }^{12}$

The antiquarian wave had given Europe the enduring legacy of Ossianism, draping the ancient Gaels in that hue of meditative otherworldliness which still inspired the Yeatsian fin de siècle (and indeed the fey Cúchulain statue, originally made by Oliver Sheppard in 1911 and moved into the GPO in 1935). The philological wave had, between 1820 and 1845, prepared the ground for the revivalists by the study of place-names, ancient texts, folklore and archaeology; names associated with these activities being John O'Donovan, George Petrie and Thomas Crofton Croker. The scholarly interest of the philological wave worked in tandem with a Gaelic-themed literary production in the mode of National Romanticism, leading from Lady Morgan and Thomas Moore to Thomas Davis and the poets of the Nation, and a rise in popular history-writing with a nativist-Gaelic focus and sympathy. No less importantly, academic philologists outside Ireland (Bopp, Pictet, Zeuss; followed later in the century by d'Arbois de Jubainville, Windisch, Meyer and Zimmer) raised the status of the Celtic languages, including Gaelic, by demonstrating its linguistic archaism and comparatist importance.

Thus, by the time Hyde issued his 'third-wave', revivalist clarion call, the cultivation of culture in Ireland rested on a tripod of academic scholarship, artistic production, and living (vernacular) culture. Hyde was inspired by all of these. He was a language enthusiast, folklore collector, amateur playwright, and literary historian, and combined all these fields of interest and expertise into a programme of revivalist activism. As a transitional figure from the second-wave philological to the third-wave activist generation, he frequently and gratefully invoked prestigious scholars like Zeuss, Windisch, d'Arbois de Jubainvile or Max Müller, and took inspiration from the philologically endorsed rise of Finnish as a national language and a national literature.

Why, it is only the other day, so to speak, that a piece of literature was found among a peasantry where least expected, taken down from oral recitation, rescued from obscurity, committed to writing, and laid before the world in a manner to merit its universal applause, and to extract from Max Müller himself the confession that the Kalewala of the Finns was the fifth epic poem of the world!13

\footnotetext{
${ }^{11}$ I have dealt with the 18th-century, antiquarian revival in Leerssen (1996a), and with the 19th-century, philological-romantic revival in Leerssen (1996b).

${ }^{12}$ These patterns are now being traced and mapped by the Encyclopedia of Romantic Nationalism in Europe (Leerssen 2015). In these pages, unspecified references to cultural-nationalist figures, trends or organisations from different parts of Europe (Catalan, Finnish, Lithuanian, etc) draw on the materials and articles posted there.

${ }^{13}$ 'Some Words about Uunpublished Literature', The Gael, 7 Jan. 1888; repr. in Hyde (1986: 81-92 (81)).
} 


\section{LANGUAGE AS ESSENCE AND MYTH: THE SWORD OF LIGHT}

The third, revivalist wave of Irish cultural nationalism, triggered by Hyde, turned from a philological historicism to a more populist, demotic approach-although the past, with mythical heroes like Cúchulain, remained an informing presence for the revivalists: the phases of cultural history do not succeed or abolish each other, but overlap in an accumulation of superadded overlays. The crucial difference between the third wave and its forerunners was, rather, the novelty of political instrumentalisation. The cultural generators in the wake of Hyde turned their cultural interest into a topical issue for contemporary society, an instrument for social mobilisation. Their platform for doing so was a language-revivalist association, the Gaelic League, founded in 1893 under the impression of Hyde's lecture 'On the Necessity for De-Anglicising Ireland'. ${ }^{14}$

For some twenty years, the Gaelic League was the great incubator of cultural nationalism in Ireland. Its membership mushroomed: the number of local branches grew from three in the founding year 1893 to 43 in 1897, more than 400 in 1903, and 964 in 1906. Social activities likewise proliferated. The Oireachtas, a successful cultural festival explicitly inspired by the hugely successful Welsh eisteddfod, was started in 1897, excursions and summer schools in the West of Ireland began in 1900, and amateur theatricals followed soon after. ${ }^{15}$

The political clout that this broad movement carried was initially turned to defending the position of Irish in the country's public sphere: in education and in public spaces. The curricular position of Gaelic, as a language of instruction or a subject in education, in the predominantly Gaelic-speaking districts and elsewhere, had been a point of debate even before the foundation of the Gaelic League; indeed, the League's precursor bodies from the 1870s and 1880s, the Society for the Preservation of the

\footnotetext{
${ }^{14}$ Online at http://romanticnationalism.net/viewer.p/21/54/object/351-187704. Eoin Mac Neill had helped to translate Hyde's lecture into a movement with a follow-up manifesto in Irisleabhar na Gaedhilge / Gaelic Journal (4.44, March 1893: 177-9) ('Toghairm agus gleus oibre chum gluasachta na Gaedhilge do chur ar aghaidh i nÉirinn / A plea and a plan for the extension of the movement to preserve and spread the Gaelic language in Ireland'); English version online at Leerssen (2015): http://romanticnationalism.net/viewer.p/21/54/object/351-252273. Tierney (1980) gives a good account of the events around the Gaelic League's foundation, and of its later radicalisation, from the point of view of Eoin MacNeill. ${ }^{15}$ An advertisement for the first Oireachtas (Rotunda, 17 May 1897, chaired by Dublin's Lord Mayor), announces it as 'a Gaelic literary festival in the style of the Welsh eisteddfod' (feis liteardha Ghaedhealach iar nos Eisteddfod na Breataine). The advertisement is reproduced in Ó Súilleabháin (1998); a very rich source for the history of the Gaelic League and its activities, especially its chapters on theatrical activities ('Tús agus fás na dramaíochta i nGaeilge', 153-225); political entanglements ('Conradh na Gaeilge agus an pholaitíocht', 245-265); and the 1916 rising ('Conraitheoirí agus Éirí Amach na Cásca 1916', 267277). Also: Mac Aonghusa (1993) and Grote (1994). Quantitative information on numbers of branches has been collated from Grote (1994), Mac Aonghusa (1993), Ó Súilleabháiin (1998) and Tierney (1980).
} 
Irish Language and Gaelic Union, had been centrally concerned with precisely this issue. ${ }^{16}$ The League gained enormous credibility among political nationalists when Hyde, in a robust polemic with Trinity College pundit J. P. Mahaffy, countered conservative attempts to back-pedal on Gaelic facilities in education in 1899-1900 (Tierney 1980: 56-7). Immediately afterwards, the League waged activist campaigns to legalise the public use of Gaelic name-forms (on shop signs and letter addresses sent through the Royal Mail); Dublin street names began to be displayed bilingually in 1901 and, famously, the only court case that Patrick Pearse (a barrister by training) ever pleaded was in defence of a shopkeeper fined for displaying his firm's name in Gaelic. ${ }^{17}$

This cultural activism garnered sympathy from the 'advanced nationalist' end of the political spectrum, i.e. separatists tending to glorify the tradition of armed insurrection; or the 'Irish Ireland' programme around D. P. Moran and the Sinn Féin programme of Arthur Griffith. ${ }^{18}$ The Sinn Féin weekly of 21 May 1910 showed an allegorical Irish maiden in 'Nationhood's Armour': her shield displaying the logo of made-in-Ireland produce (playing into the party's programme of economic self-sufficiency), her sword marked with the words 'Irish Language' (figure 3).

Certainly from 1913 onwards, the Gaelic League converged with political nationalism and outright separatism, much to the chagrin of Hyde, who had never intended to see his cultural agenda thus yoked with actual separatism. Whether this is a result of infiltration by Irish Republican Brotherhood (IRB) conspirators or a political hardening of attitude among the revivalists themselves is hard to decide; both processes can be documented, and probably they operated in tandem. Be that as it may, five of the seven signatories of the 1916 proclamation (Pearse among them) had been committed early members of the Gaelic League, moving from its cultural revivalism to armed separatist insurrection, to end up in the Dublin Post Office (figure 4).

\footnotetext{
${ }^{16}$ In Gearóid Ó Tuathaigh's pithy summary: 'By the late 1870s Irish (called "Celtic") was accepted as a subject for examinations in secondary school state exams. It was then admitted as an "extra subject" in primary schools, but with limited impact initially. The Gaelic League maintained pressure. In 1900 Irish was accepted as an "ordinary" subject, and in 1904 the government's Commissioners on National Education introduced a Bilingual Programme, with a detailed syllabus in Irish and English for each grade of the primary schools, taking account of the differences between Irish-speaking districts and others' (2008: 26-7). The educational pressure was kept up: in 1908, Pearse set up a school (St. Enda's) on national-revivalist principles; and as in that same year the National University system was being established, activists like Mac Neill campaigned to have Gaelic adopted as a matriculation requirement. This did not fully materialise until after independence; and the actual impact of linguistic nationalism in education appears to have been minor in comparison with the fervent nationalism that was inculcated through the teaching of Irish history as a school subject.

${ }^{17}$ Mac Mathúna (2004: 56-7) discusses street sign policy, the postal addressing campaign and the conflicts over Gaelic shop-signs, and points out that An Claidheamh Soluis offered helpful lists of Gaelicised surnames for those who wished to adopt Gaelic name-forms.
}

${ }^{18}$ D. P. Moran, 'The Pale and the Gael' (1899), included in Moran ([1905] 2006); Glandon (1985). 


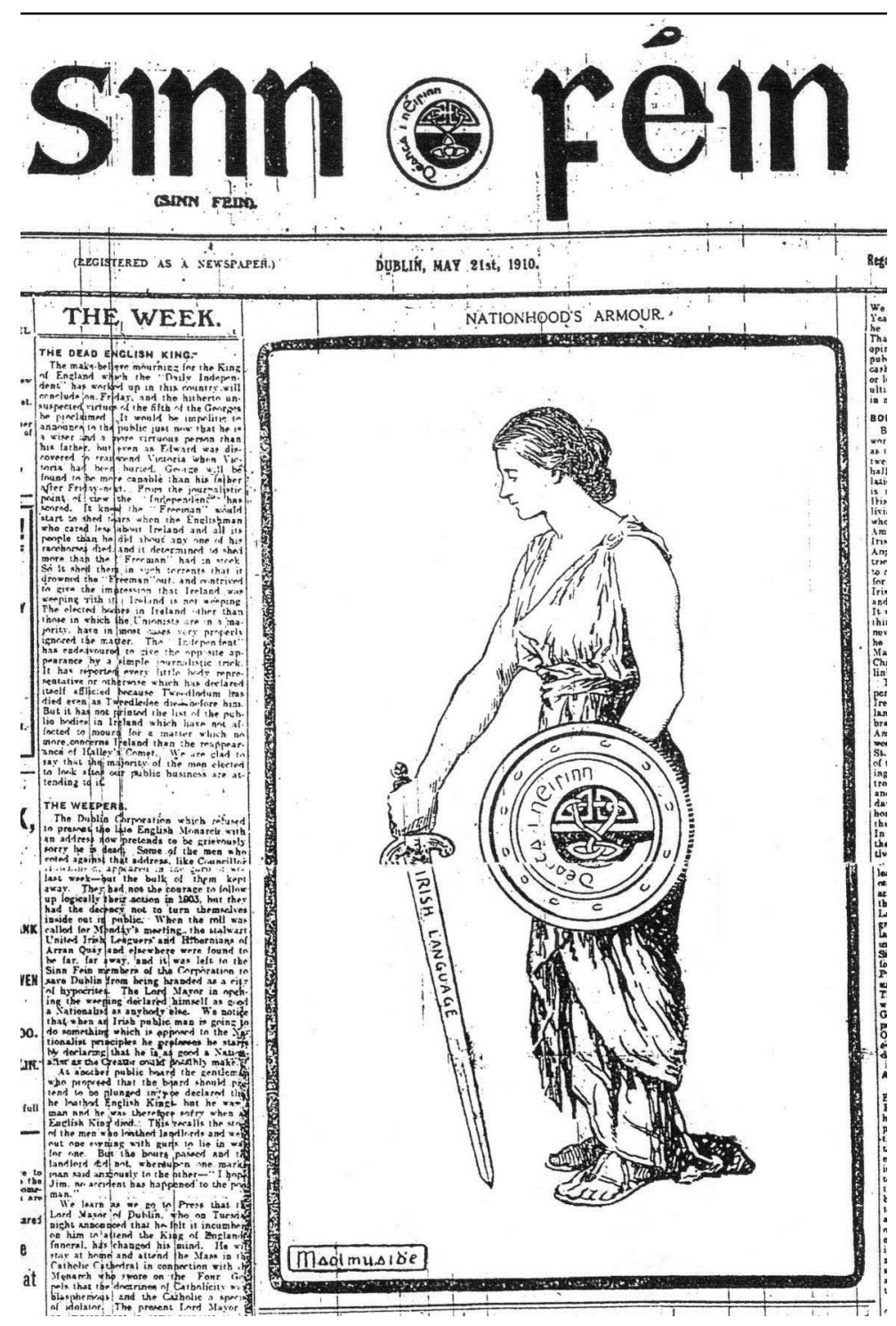

Figure 3. 'Nationhood's armour': allegorical cartoon by 'Maolmuaidhe', Sinn Féin, 21 May 1910.

Hence the resonance of de Valera, 1916 veteran and soon-to-be-called-taoiseach, unveiling a Cúchulain statue in the GPO in 1935. In the symbolical presidency of Hyde, and in the telescoping channelling of Pearse channelling Cúchulain, we see, not only a dovetailing of the modes of filiation and affiliation, but also the outlines of a master narrative which is still to a large extent with us. Cúchulain in this model stands for the cultural bedrock that gives the Irish nation its fundamentally and irreducibly Gaelic ethnic identity; Hyde stands for the generation of cultural intellectuals and 
idealists who attempt to rescue this native tradition from the wreckage of Englishimposed alienation; and Pearse and the General Post Office stand for the armed recuperation of the Gaelic-based national autonomy. In this master narrative, successive champions from century to century are said to have passed on an essence of Irish nationality like the baton in a relay race. That relay-race image of transgenerational tradition was forcefully expressed, in 1939, by Desmond Ryan's The Sword of Light: From the Four Masters to Douglas Hyde, 1638-1938 - the author being himself a former Gaelic League member and 1916 combatant. And what holds his master narrative together, from Golden Age, through wreckage, salvage and revival to ultimate vindication, is the Irish language itself.

The Irish language in this master narrative is the very embodiment of Irish nationality: it is the nation's container, its expression, its platform, its substance, and the barometer of its viability. From an idealised antiquity with native Gaelic culture paramount in all its glory, Irish history moves to the degradations and fractures of colonial oppression and pauperisation. The 17th and 18th centuries witness the loss of high literature and then even of literacy itself; the 19th century leads into the catastrophe of the Great Famine of the 1840s and the threatened extinction of the language altogether.

From this crisis, the narrative becomes more buoyant: vestiges of the culture survive in isolated pockets of learning. In a nick-of-time partnership, the last guardians of native learning and the first generation of modern intellectuals salvage the precious tradition of language and nationality. The re-contextualisation, indeed the transmigration of Gaelic culture, so the narrative continues, would eventually inspire a nationalist movement that, following on many earlier failed attempts, was finally successful because it could now draw on the true mainspring of the Irish nation: its language, culture and tradition. That is how the heroic strength of Cúchulain (himself a powerful and inspiring myth in his own right ${ }^{19}$ ) can migrate, almost in metempsychosis, down the generations, across intermediaries like the Ulster Earls, Eoghan Rua O’Neill, and Wolfe Tone, to end up in the mundane setting of the General Post Office.

\footnotetext{
${ }^{19}$ As Rafroidi (1983: 138) notes, contemporaries were already aware of this nation-building potential of Gaelic myth. The philologist Eleanor Hull, in her edition of The Cuchullin Saga (1898) noted the indispensability of the 'historic imagination' for patriotism, and Lady Gregory, in her version of Cúchulain of Muirthemne (1902), asserted that 'Ireland was ready for the Cúchulain myth just as Germany, overshadowed by cosmopolitan France, had been ready for the Siegfried one'. Cf. also Sisson (2005) on Pearse's use of Cúchulain as an educational role model.
} 


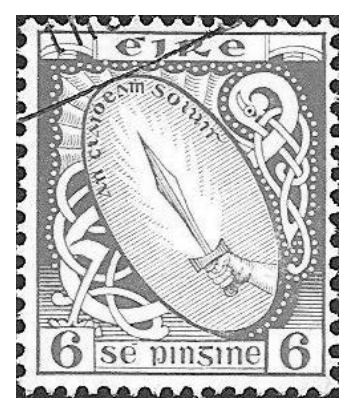

Figure 4. Irish postage stamp with Claidheamh Soluis motif (in use between 1922 and 1968).

This metempsychotic view ${ }^{20}$ of a national essence transmigrating across successive avatars was central to how the cultural nationalists saw themselves, their nationality and their agenda. Pearse himself, in the 1916 proclamation, invoked the 'dead generations' and their iterations of resistance-in-arms as a continuity principle to justify the 1916 bid for independence. This was, in fact, the nationalists' way of re-phrasing their affiliation into the terms of a filiation, and as such (a quasi-filiation $^{21}$ ) it is probably not even peculiar to the Irish case; rather an inherent characteristic of the historicism that lies at the core of cultural nationalism generically. The 'Sword of Light' mentioned in Ryan's title is like the transmigrating spirit of Cúchulain (figure 4). A magical, invincible Light Sabre mentioned in ancient Gaelic myths, it was now interpreted to refer to the language itself, becoming the title of the journal of the Gaelic League (in Irish: An Claidheamh Soluis). The editor of that periodical was Patrick Pearse.

\section{LANGUAGE AS GESTURE}

Of course the 'Sword of Light' is, properly speaking, a myth: a supernatural tale from the past which appears symbolically applicable to deep historical patterns. While myths may give us a good sense of how people saw or experienced things, they are not trustworthy or reliable as historical explanations. For one thing, the actual strength of the language in 1916 was by no means sufficient to support its enormous symbolical, even mythical, importance. Outside a few rural districts, Gaelic existed only as an object of affiliation, not as a living means of public-sphere communication.

Indeed, in this respect the Sword of Light narrative is quite true to fact: the revival came almost at a last-opportunity salvage moment. One of the remarkable aspects of Gaelic-language revivalism is the fact that its upsurge took place exactly in the decades that the language itself went into a steep decline (cf. Fitzgerald 1984). While some recent historians (Morley 2011; Wolf 2014) stress what they perceive as a robust or

\footnotetext{
${ }^{20}$ For Joyce's thematisation of metempsychosis in Ulysses, see Leerssen (2012). Thomas MacDonagh wrote a one-act play called Metempsychosis: Or a Mad World (1912), a satire on the esotericism of rarefied Anglo-Irish writers like Yeats and George Russell ('A. E.').

${ }^{21}$ Reframing a cultural affiliation in the mythical-transcendent terms of a pretended filiation may explain the undertone of uneasiness and doubt in Yeats's lines 'When Pearse summoned Cúchulain to his side, what stalked through the Post Office?' The question is not rhetorical, nor even WBY-style 'darkly suggestive'; it poses the problem of quasi-filiation which Yeats can intuit but is unable to resolve. What indeed?
} 
vibrant presence for the language in the opening decades of the 19th century, the mid-century famines dealt it a devastating blow. Gaelic was not so robustly entrenched or vibrantly resilient that the famine's survivors should cling to it in the second half of the century. By the 1870s, Gaelic was shrinking geographically to the country's rural periphery, socially to a poverty-stricken peasantry prone to emigration, and culturally to an oral-traditional, backward lifestyle. This inverse proportionality between language usage and language activism would at first sight seem to fit an obvious supply-demand logic (the value attributed to a given cultural feature rises as it becomes more of a rarity; or, as Joni Mitchell put it, 'you don't know what you've got till it's gone'). Narratologists may also be struck by the mythical resonance of a 'retrieval from the edge of perdition' narrative, which echoes from Moses's basket on the Nile to Luke Skywalker in the Star Wars saga. But the fact stands that the correlation between language decline and language revival is much more salient in the Irish case than in other European minority cultures or national movements. Finnish, Lithuanian, Flemish or Catalan language movements were less driven by a salvage need, and more by social assertion.

This also accounts for the relative lack of overlap between native speakers and revivalists/activists (also much more salient in Ireland than in other minority-language movements). Very few of the separatists of the generation of 1916 hailed from a Gaelic-speaking background, ${ }^{22}$ almost all had learned it as a second language, some in early or late childhood, most as part of their early-adult commitment to the revivalist cause. Tellingly, Pearse's 1916 proclamation uses Gaelic only in what we can call, technically, the paratext: the textual material surrounding the actual main body of the message. The masthead identifies the proclamation by the Gaelic words, Poblacht na hÉireann (Republic of Ireland); and only two out of the seven signatories give their names in the Irish name-forms-Sean Mac Diarmada (John McDermott) and Eamonn Ceannt (Edward Kent). Remarkably, Pearse himself opted for his English name-form rather than Pádraig Mac Piarais.

Similarly, in subsequent, post-1916 nationalist politics, most usage of Gaelic was either paratextual or nominal (i.e., restricted to the register of proper names): the names of political parties like Sinn Féin, designations like Poblacht na hÉireann, Dáil,

\footnotetext{
${ }^{22}$ One such case being the hunger striker Thomas Ashe, from Lispole, Co. Kerry: not only was Lispole a Gaelic-speaking district, but his father Gregory was fully bilingual and a committed language enthusiast. A native knowledge of the language had been more strongly represented among the intellectuals of the previous (mid-19th-century, philological) wave: Hardiman, O'Curry, O'Donovan, MacHale. Hyde himself acquired some informal Gaelic in childhood (from the estate's gamekeeper, who died when Douglaswas 14) and dedicated himself more seriously to its study as a student. Later memoirs still refer to occasional lapses in his command of the language (e.g. Mac Neill in 1918: 'his English is fluent and musical, his Irish always imperfect': quoted in Tierney (1980: 177)).
} 
or Taoiseach. Indeed, this nominal and paratextual usage was denounced as 'ornamental' as early as 1920 by one of the revivalists to have a practically native knowledge of the language, Pádraic Ó Conaire.

These friends who are not real friends [of the language] treat and praise the language as a kind of ornament like the flashy uniforms worn by the Ancient Order of Hibernians. If they have a little word on top of their writing paper ... they believe they have done their duty ... Gaelicism for them is ornamental. For the best of them it is ornamental, for the worst a votecatcher - that Gaelicism which is the backbone of our nation..$^{23}$

Ó Conaire's critique has echoed down the decades. Throughout the century, the state's official invocation of the Irish language as its 'Sword of Light' has been consistently accompanied by reproachful comments that this was a matter of mere tokenism, a superficial gesture. English-derived institutions and social patterns, indeed, an Englishderived modernity, were overlaid with the merest varnish of linguistic nativism. Ironically, this tradition of critique is the strongest and most abiding result of the revival of the Irish language: its self-dissatisfaction; the rage against official piety and tokenism; the ubiquitous, incessant, never-satisfied, obsessive denunciation of its own insufficiency. From the outset, the fact that for most revivalists, Gaelic was at best a schooled acquisition (an affiliation) and rarely a natural environment or native childhood inheritance (a filiation), saddled the de-Anglicisation programme with a nagging soupçon of artificiality.

The initial cleavage between actual speakers and language revivalists, between gesture and praxis, is perpetuated in post-revival Ireland's half-acknowledged anxiety at the mismatch between myth and reality, symbolism and substance; between the primitive warrior Cúchulain and his middle-class bourgeois reincarnations. These anxieties result, in my view, from the asymmetry between the thinness of actual cultural filiations (like parent-to-children language transmission) and the overcompensating gestures of cultural affiliations.

But, anxieties aside, there is also a retrospective projection at work, an imputed agenda falsely imposed on the revivalist generation by their separatist post-1919 successors. The generation of Miss Ivors has been constantly measured, in retrospect, not by what they themselves wanted to do, but by what nationalists in retrospect felt they should have prepared.

\footnotetext{
${ }^{23}$ Quoted in Ó Huallacháin (1994): 81). Ó Conaire, born Patrick Conroy in Galway in 1882, acquired his fluency in Gaelic after he had moved in with relatives in Connemara in 1893 (when, at the age of 11, he was orphaned).
} 
The Sword of Light narrative, powerful myth though it was (and is), is untrustworthy as a historical frame for understanding what actually went on between 1893 and 1916. To begin with, it is finalistic - that is, it writes history merely as the run-up to what we now know to be its outcome. The historical importance of Hyde and his followers is seen purely as that of political facilitators: the cultural starter engine for the separatist Big Push. Hyde's explicit refusal of that role is seen almost condescendingly as a piece of political naiveté: what had he been thinking? How could a lecture proclaiming the need for de-Anglicising Ireland pretend that its purport was non-political? And so the benefit of hindsight lures historians into the trap of second-guessing their sources.

The cultural generators of the run-up to 1916, that Motley Coalition of middle-class feminists, academics, Protestant patricians and snobs, village priests and white-collar workers, were more than a mere cultural warming-up exercise. Their cultural production endowed Irish politics, largely mired in the ephemeral minutiae of partisan conflict and petty current affairs, with a prestigious 'national' charisma, and lifted it to the transcendent symbolical status of a 'national cause'. And was language engineering ever really their point?

\section{LANGUAGE AS SYMBOLIC AMBIENCE: THE CULTIVATION OF CULTURE}

Did the revivalists really entertain the quixotic notion that in a 'war on Anglicisation', Gaelic was to displace English as the country's main language? That is not, in fact, what Pearse meant by 'Gaelic and Free'. For Pearse, linguistic commitment was not, as he called it 'the be-all and end-all':

The preservation and extension of spoken Irish is officially the primary object of the [Gaelic] League; but we suggest if there be Gaelic leaguers, 'rabid' or otherwise, who regard the speaking of Irish as the be-all and end-all of the movement, they have yet to grasp the movement's inner meaning; for our final goal is Irish nationality, and we value the language not solely or even mainly for anything that it is in itself, but chiefly because it is an essential of Irish Nationality. ${ }^{24}$

In this context, the notion of Irish Nationality refers to the self-awareness of possessing a separate cultural identity. And this is also what the language meant: its existence and invocation helped establish a self-awareness of possessing a separate cultural identity. Pearse here follows Douglas Hyde himself. The title of Hyde's seminal lecture, The Necessity for De-Anglicising Ireland, can easily be misread. Hyde never seriously

${ }^{24}$ An Claidheamh Soluis, 20 August 1904. Also quoted in Ó Súilleabháin (1998: 247). 
proposed to oust the English language from Ireland. He explicitly admitted, in the lecture, that 'to keep the Irish language alive where it is still spoken' is 'the utmost we can at present aspire to'. In 1886, he had been even more explicit:

There is no use in arguing the advantage of making Irish the language of our newspapers and clubs, because that is and ever shall be an impossibility; but for several reasons we wish to arrest the language in its downward path, and if we cannot spread it (as I do not believe we very much can), we will at least prevent it from dying out and make sure that those who speak it now, will also transmit it unmodified to their descendants. ${ }^{25}$

What Hyde's lecture proposed was a re-appreciation of the Irish language as a symbolical presence, in order to establish a basis from which to resist a general cultural modernisation process, experienced as a vulgarising decadence, and identified as Anglicisation after its land of origin. The ethnic markers Gaelic and Anglicisation were to a significant extent stand-in terms for the notions of cultural authenticity and decadence.

The defining characteristic of the Gaelic League's Gaelic revivalism was that it used language as an ambience or platform, a means rather than an end, and that its actual pragmatic targets were to a large extent non-linguistic. The Gaelic League's revivalism targeted social spheres and cultural fields such as music, dance, dress, literature and the theatre. The Gaelic language was the operating system, not the ultimate end-goal, of a Gaelic revival. The broadly cultural programme was revivalist; the narrowly linguistic programme was merely preservationist. The aim was to preserve Gaelic from dying out altogether, not to universalise its usage. As an advertisement for the newly founded Gaelic League phrased it: 'This Association has been founded solely to keep the Irish language spoken in Ireland'-echoing the actual wording of the League's founding resolution 'that a Society be formed under the name of the Gaelic League for the purpose of keeping the Irish language spoken in Ireland'. ${ }^{26}$

This language activism was also, avowedly and from the very beginning, a matter of symbol politics. I do not mean that term in a derogatory sense (like Ó Conaire's 'ornamentalism') but with Bourdieu's notion of symbolic capital in mind. ${ }^{27}$ The primary aim was to raise the language's profile (from a marker of backwardness and

\footnotetext{
${ }^{25}$ 'A Plea for the Irish language', Dublin University Magazine 1886, reprinted in Hyde (1986: 74-80).

${ }^{26}$ Advertisement in the Gaelic JournallIrishleabhar na Gaedhilge, June 1894; also, Mac Mathúna (2004: 51).

${ }^{27}$ Bourdieu has developed, and drawn on, the notion of symbolic capital (now almost a colloquialism) in many of his writings, most notably his standard work La distinction (Bourdieu 1979). It refers to the non-economic value attributed to certain (usually cultural) artefacts or practices, which are considered capable of investing those associated with it with 'social capital' (i.e. prestige). As such, symbolic capital may count both as a viable alternative to economic capital and as the positive opposite of stigmatisation.
} 
peasant poverty, which is how it was seen in some conservative quarters and, to some extent, also by those native speakers who had scant fondness for the poverty and backwardness with which it was associated) to that of an indispensable, informing force in the field of culture generally. What mattered most about Irish was what it symbolised, not socially, but culturally: a culture impervious to creeping assimilation into a modernity made-in-England. Under the name of 'Anglicisation', Hyde denounced modern vulgarity in general: from the yellow press to music-hall songs like 'Ta-ra-ra-boom-de-ay'. The Irish adoption of this vulgar modernity Hyde saw as a fatal self-alienation. To resist it, a cultural revival was needed, and the Gaelic language, restored to a robust social prestige, provided the auspices under which that cultural revival could be undertaken.

We should add that Hyde's agenda proved eminently successful in this respect: in everyday politics, any stance invoking Gaelic culture or the language was immediately lifted out of the drab arena of contentious interest-vindication into the more prestigious sphere of the 'national cause', being thus invested by that symbolic capital which the revival programme managed to accrue for the Gaelic language and cultural traditions.

Language, in the usage of these decades, becomes a proxy term to indicate that a society is held together by shared descent, is ethnic rather than civic in nature, is a cultural rather than a political entity. As Pearse put it in 1905,

Language is at once an important element itself, and a safeguard of other important elements, at once a test and a symbol of nationality ... it is a preservative not merely of the literature and folklore of the nation, but of the nation's habits of thought, the nation's popular beliefs ... It is a preservative also of nationalism in art, in industry, in pastimes, in social and civic customs. ${ }^{28}$

Language preservation (note how the language, from being an object of preservationism, becomes its agency) protects against the creeping trend of de-ethnicisation. As a result, the language was used for leverage rather than for actual communication; it was invoked, as a prestige-dispensing principle, rather than spoken.

Ironically, this means that language, invoked as an enabling cultural operating system, was in fact (despite Pearse's protestations to the contrary) made use of, as an end rather than as a means: to demonstrate its usage and viability rather than to convey content or to communicate. We may clarify this by viewing the public use of Gaelic in terms of its communicative functions as classified by Roman Jakobson (1960). Following Jakobson, linguistic communication can be used with a variety of functions, from referential (describing a situation) to poetic (highlighting its own

${ }^{28}$ 'Language and Nationality', An Claidheamh Soluis, 4 February 1905. 
textual charm), and including such functions as the emotive (attention-grabbing exclamations), the conative (giving instructions or orders), the reflexive (language about language) and the phatic (inconsequential uh-huh signals confirming that the lines of communication are functioning). One gets the impression that the balance between, on the one hand, the referential, and on the other hand, the reflexive, emotive or phatic function in Gaelic usage tends to slant towards the latter-which is what Ó Conaire denounced as 'ornamental', but which in fact is a telling indication of how language was drawn on primarily for purposes of symbolical identity assertion and prestige enhancement.

Hyde harnessed these symbolical functions of language most specifically in the field of proper names of places and persons. This nominalism was as effective in his day as that of 1970s feminist campaigns against gender-skewed words like 'chairman'. In fact, what takes up most of Hyde's lecture (though it is often left out in the abridged versions one finds online) are page-long disquisitions with endless lists of examples on how place-names, family names and given names were alienated from their native roots and replaced by English-imported vulgarity. As a sampler I give a muchcondensed excerpt (lifted out of a much longer harangue, with the Gaelic etymons filtered out).

We find the decay of our language faithfully reflected in the decay of our surnames. The Mackays are Hughes. The Mac Reevys or Mac Culreevys are Grays. The Mac Eóchagains instead of being all Gahagans or Geoghegans have deformed their name into the monstrosity of Goggin. The Mac Feeachrys are Vickors or even Hunters. The honourable name of Mac Rannell is now seldom met with in any other form than that of Reynolds. The Mac Sorarans have become Somers. ${ }^{29}$

On the topic of given names, Hyde writes:

Such common Irish Christian names as Conn, Cairbre, Farfeasa, Teig, Diarmuid, Kian, Cuan, Ae, Art, Mahon, Eochaidh, Fearflatha, Cathan, Rory, Coll, Lochlainn, Cathal, Lughaidh, Turlough, Éamon, Randal, Niall, Sorley, and Conor, are now extinct or nearly so. Angus, Manus, Fergal, and Felim are now hardly known. The man whom you call Diarmuid when you speak Irish, a low, pernicious, un-Irish, detestable custom, begot by slavery, propagated by cringing, and fostered by flunkeyism, forces you to call Jeremiah when you speak English, or as a concession, Darby. In like manner, the indigenous Teig is West-Britonised into Thaddeus or Thady, for no earthly reason than that both begin with a T. Donough is Denis, Cahal is Charles, Murtagh and Murough are Mortimer, Domhnall is Daniel ... Eoghan (Owen) is frequently Eugene ... [etc.]

${ }^{29}$ The full text is online at Leerssen (2015) and http://www.spinnet.eu/images/2014-05/hydenecessity.pdf. 
For the women's names, the lecture proffers effusive arguments in favour of Sadhbh, Nora, Una, Maeve, Eibhlin, Aoife, Sighle, Máirín, Nuala and Fionnuala. (Hyde admits to a dislike of Sinéad and Siobhán; they 'sound so bad in English that I do not very much regret their being translated into ... Jane and Joan').

What strikes the present-day reader is that many of these names, mentioned by Hyde as neglected or almost-vanished traces of an abandoned past, are nowadays very much alive and kicking. As with the names of state institutions, so too the most outstanding success of Hyde's programme of de-Anglicisation lies in the field of nominalism: proper names.

At the time, the followers of Hyde and his Gaelic League even undertook a deliberate Gaelic transnomination of their name forms. I have mentioned that only two of the signatories of the 1916 proclamation used their Gaelic signatures, Seán Mac Diarmada and Eamon Ceannt. Pearse and Clarke signed as Pearse and Clarke; but the former had written and published in the years before as Pádraig Mac Piarais, and the latter had given his tobacconist's shop a staunchly Gaelic shop-sign in Gaelic lettering stating the owner to be, not Thomas Clarke, but Tomás Ó Cléirigh. Indeed, it comes as a surprise to see how many household names from early-20th-century Irish history were in fact self-chosen acts of de-Anglicising purgation. Eugene Curry is praised by Hyde for 'pluck[ing] up the courage to prefix to $\mathrm{O}$ to his name in later life', Eugene O'Growney's name was nativised into Eoghan Ó Ghramhnaigh, Eoin MacNeill began his life as John McNeill; and Hyde himself, if he did not use the pen-name An craoibhín aoibhinn, transmogrified his name into Dubhghlas de h-Íde. A de-Anglicisation? Hardly. Many of these self-imposed Gaelic names are not a return to an older original, but rather a pseudo-Celtic drapery cloaking a decidedly English original. Piaras Béaslaí began life as Percy Beazley, Cathal Brugha had been originally christened Charles St. John Burgess. The man who in 1937 gave his office-of-state the tribal name of Taoiseach, Éamon de Valera, had been born as George de Valero. His wife Sínéad de Valera was née plain Jane Flanagan. ${ }^{30}$ Around 1903, she changed her name to its Gaelic analogue Sínéad Ní Fhlannagáin, and upon her marriage in 1910 became the Sinéad de Valera familiar to 20th-century Ireland. Her husband George/ Edward/Éamon de Valero/a, who had been her language pupil since 1908, likewise used the wedding to finally settle his name-form.

Significantly, the 'Sword of Light' narrative tends to identify all these actors simply and straightforwardly by their eventually chosen Irish name-forms, thus filtering their deliberate and sometimes counter-intuitive acts of nominalist self-reinvention

\footnotetext{
${ }^{30}$ Press notices of a performance of Douglas Hyde's Gaelic-language play An Tincéar agus an tSídheóg, in 1902, praised 'Miss Jane Flanagan' for her fine acting: quoted in Ó Súilleabháin (1998: 155).
} 
out of the historical record. This tendency to 'retcon' the past ${ }^{31}$ is one of the more egregious forms of counterfactual affiliation. The Sword of Light narrative saddles the language activists with motives that we feel they ought to have had, the failed realisation of which we then regret or denounce. The gesture is all the more insidious because the current state still uses Gaelic for ceremonial purposes, including the commemorative centenary of 2016, and will by that affiliative usage of Gaelic project today's situation back onto the commemorated event and its protagonists as if it were their intended outcome. What that can lead to can be seen from the recent concoction of a contrafact of Pearse's 1916 Proclamation of Independence, retconned into Gaelic, explicitly devised for possible use 'in commemorative events'. ${ }^{32}$

Historians must take care, therefore, to disentangle our understanding of the revivalists' actual agendas from the retconned single-mindedness that was imposed on them by latter-day commemorative acts of affiliation (or, in some cases, their selfmythologisation ${ }^{33}$ ). Their agenda was part of the European turn-of-that-century, and, I repeat, deliberately nominalistic and symbolically prestige-raising. It was also deeply contradictory in that it saw the language as an operating system for other cultural fields, while limiting its usage largely to the symbolical or self-referential. That is also borne out by the campaigns vindicating phatic usage in the public sphere-something which nowadays we would call 'branding' - on shop signs, street and village names, and postal envelopes. Gaelic branding also involved the visual signal of the Gaelic letter-font as a deliberate act of typographical de-Anglicisation. But such linguistic symbol politics aside, the de-Anglicisation programme used Gaelic largely as a lever to nativism in a broad programme of cultural fields: sports and leisure excursions, music and dance, and above all: drama.

\footnotetext{
${ }^{31}$ The term, a contraction of 'retroactive continuity', comes from the world of TV serials and multiinstalment narratives, where sometimes the back story of certain characters is adapted retroactively so as to obviate clashing inconsistencies or 'continuity errors' with subsequently introduced events or situations. An example is J. R. R. Tolkien reworking certain elements in later re-editions of The Hobbit (originally published in 1937) in order to achieve consistency with The Lord of the Rings (1954-55).

32 'Easter Proclamation in Irish', on the Conradh na Gaeilge website cnag.ie at https://cnag.ie/ en/2016-commemoration/easter-proclamation-in-irish.html (written 13 November 2015, consulted 6 May 2016). The spelling follows the post-1945 Caighdeán oifigiúil: the language ventriloquised in this text is that of 2016 .

${ }^{33}$ Hyde as a young student liked to present himself as a lineal straightforward descendant of Ireland's native culture: cf. Ó Glaisne (1994: 60-61); Eoin Mac Neill is gushingly presented on the opening page of his biography (Tierney 1980: 1) as a descendant 'from Ó Néill of Cinéal Eoghain and of Clann Aodha Buidhe', said to hail 'from old Gaelic and galloglass families'. Tierney also asserts, for reasons unspecified, that MacNeill's father's name Archibald should be read as 'an anglicised form of the traditional Giolla Easpuig'. Thus affiliative retconning eats into the historical record.
} 
The amateur theatricals around the Gaelic League were an important part of revival culture; ${ }^{34}$ from the convivial sociability of Gaelic League members and sympathisers they spilled over into the more upmarket avant-garde agenda of Yeats's Literary Theatre. Revivalists like Alice Milligan and the highly regarded actress Mary Walker (who changed her name to Máire Nic Shiubhlaigh and participated as a nurse in the 1916 Rising) have been relegated to a subsidiary position in Abbey-centred accounts revolving around the triad of Yeats, Lady Gregory and Synge. But regarded in their own right (as per Trotter 2001), they highlight the important performativedramatic aspect which grew out of revivalist movement, and which can be traced from the boy dramas at Pearse's St. Enda's School right into the performative self-staging of the Easter Rising (Sisson 2005). In the theatre, too, language is in the eye of the storm. The Irish Literary Theatre began, and achieved its formative initial success, as a joint venture between Yeats's Literary Society and the amateurs around the Fay Brothers and Maud Gonne's nationalist-feminist agitprop group Inghinidhe na hÉireann. The fact that Yeats opted for English tended to make him, Protestant snob, suspect in the eyes of the Irish-Irelanders; but then again the Irish-Irelanders' appreciation of Douglas Hyde's Gaelic one-acts sketches must have been largely for symbolical reasons, because they were hardly able to follow them. Significantly, Gaelic theatre has close connections with dumb show; it started with the silent, motionless tableaux vivants staged by Inghinidhe na hÉireann, and had interesting medial overlaps with magic-lantern shows and the emerging silent movie. Language is, quite literally, everywhere and nowhere.

\section{THE EUROPEAN CONTEXT, AND ITS ELIMINATION AFTER 1914}

Famously, the Dublin theatricals were deeply inspired by the example of the Norwegian National Theatre in Bergen, the launching platform of Henrik Ibsen and a shining example to minority cultures all over Europe: how amateurs with limited means could create high-prestige modern art. The amateur-based art theatre of Dublin in turn inspired similar ventures in Iceland and Finland. And as with drama, so too with other cultural fields (music, dance, sports, etc). In each of these trends, there were similar movements all over Europe, manifesting themselves in similar form in countries as far apart as Iceland, Lithuania, Bulgaria and Catalonia. It is important to stress

\footnotetext{
${ }^{34}$ Cf. Ó Súillebháin (1998: 153-225); Foster (2015: 75-114, chapter 3, 'Playing'). The wider documentation is gathered in Hogan \& Kilroy (1978-80). Also Trotter (2001: 73-99). On the pre-history of the tableau vivant: Holmström (1967). On Alice Milligan and Inghinidhe na hÉireann, some comments in Foster (2015), and more centrally, Morris (2013) and Pašeta (2013: 33-62).
} 
this point since our understanding of the activist generation is all too frequently blinkered by a distortive methodological nationalism, an internalist tunnel-vision. Irish cultural history, clamped in the vice of the neighbouring hegemon, is often analysed along exclusively intra-Irish sociopolitical lines of causality: as expressions of Irish social relations triggering Irish political actions. But as can be gathered from previously mentioned examples (the symbolical prestige derived from international philologists; the inspiration of the Eisteddfod; one might add Boer War activism, Pearse's interest in bilingual educational experiments elsewhere in Europe, or Griffith's in Habsburg constitutional devolution), Irish cultural nationalism was to a large extent fed and fanned by European trends. It was, in fact, the Irish manifestation of a Europe-wide trend. Romantic Nationalism and the historicist and nativist 'cultivation of culture' were not so much triggered by Catholic Emancipation, the Famine, or the Parnell crisis, as they were imported from Europe, inspired by German, Finnish, Welsh or Flemish examples. An internalist focus will often relegate such international inspirations, contacts or analogies to the edge of our vision, as interloping incidents flitting across the 'real' core developments, flagged anecdotally as obiter dicta; and that imbalance should be redressed by a more comparatist, transnational reconsideration.

Transnomination, for example, was by no means limited to Ireland. In the Baltic lands, cultural activists could rename themselves at will between Polish, Russian, Belarusian/Ruthenian, Lithuanian, German or Estonian name-forms. Jewish revivalists coming out of the Haskalah-movement, who abandoned Russian or Yiddish in favour of Hebrew, changed their names from Eliezer Yitzhak Perlman or Ascher Zvi Hirsch Ginsberg to Eliezer Ben-Yehuda and Ahad Ha'am, respectively. More remarkable perhaps is the case of Finnish, which was raised from mere rustic speech to the status of carrying public-sphere communication and cultural production. Whatever the conditions were which made this revival more successful than those of Occitan or Gaelic, it too was accompanied by transnomination away from Swedish. The artist Axel Waldemar Gallén became Akseli Gallen-Kallela, the politician Georg Zakarias Forsman became Yrjö Sakari Yrjö-Koskinen. And in Hungary, names were Magyarised in great number in the climate of Romantic Nationalism: the national poet Sándor Petöfi was born under the Slovak name Alexander Petrovics. ${ }^{35}$

Even Miss Ivors's excursions to the Gaelic West are part of a European trend. Nationalism as an urban regeneration movement often combined the ideas of back to culture and back to nature; the excursionistas of Catalonia being perhaps the most

\footnotetext{
${ }^{35}$ This, incidentally, throws an interesting sidelight on the name of the protagonist of James Joyce's Ulysses. Leopold Bloom's father was an immigrant from Hungary, with the Hungarian name Virag, later Anglicised to Bloom. In fact many Hungarians named Virág (the word means 'Flower') had transnominated themselves from the older name-form Blum; cf. Mecsnober (2013: esp. 41-2).
} 
obvious analogue, with their cultural hiking-trips to the Catalan countryside and mountains. Physical regeneration also explains the Europe-wide link between nationalism and sports, from the Sokol clubs in Central and Eastern Europe combining athletics, gymnastics and pan-Slavism, to Ireland's own Gaelic Athletic Association. Indeed, the GAA, which had gone through a slump in the later 19th century, was revived as a result of its connection with the Gaelic League. It adopted a de-Anglicisation programme and a technical vocabulary in Irish (Mantle 1983).

A great many fields could be enumerated in which middle-class sociability and revivalism triggered cultural production and provided a platform for political mobilisation between 1895 and 1915; but the pattern may already be clear by now. In all cases the language provides the allure and symbolical stature of the pursuit in question as a national enterprise; in all cases we see, moreover, that the pursuit is in fact part of a transnational pattern. The message is national, but the vehicle is pan-European.

On that basis we can identify those fields in which Irish revivalism was comparatively strong in the European scheme of things, and those in which it was comparatively feeble. Nationally minded education was a long-standing central concern, and more prominent in Irish activism than in other national movements, from the establishment of the Christian Brothers and of the Society for the Preservation of the Irish Language to Pearse's pedagogical programme. Theatre, characteristically expressing a Gaelic nationality through a language that was not Gaelic, was also exceptionally prominent. But the revival of national dress, highly successful in Scotland, Bavaria and the Baltic countries, amounted to no more than an abortive attempt to introduce kilts and ladies' cloaks, failing to survive 1916.

Again, music and dance were remarkably successful, and remain so to the present day. The Oireachtas cultural festivals featured traditional singing, piping, fiddling and dancing; a regular Piper's Club (Cumann na bPiobairí) was established by Eamonn Ceannt, the future 1916 insurrectionist. (Ceannt's musical talent won him a gold medal at the 1906 Oireachtas.) But on the other hand, a mobilising platform that was extremely important across Europe, from Wales and Catalonia to the Baltic and Bulgaria, was noticeably absent in Ireland: that of the choral society. Choirs and choral festivals were among the great cultural mobilisers of national feeling in many European countries (Lajosi \& Stynen 2015) — but not in Ireland. Singing cultureincluding a not inconsiderable repertoire in Gaelic - instead took the more individual form of ballad-performances in private households or informal-convivial surroundings; it provided an important, diffuse medium for the performative dissemination of patriotic and nationalist verse, building on a canonical repertoire going back to Moore's Irish Melodies and the Spirit of the Nation songbook. Again, a similar pattern of recycling national songbooks in a performative-convivial setting can be observed 
in Denmark and Germany. ${ }^{36}$

Despite the fundamental notion of de-Anglicisation, the transnationalism of these initiatives did not exclude England (e.g. in the field of folk music collecting, witness the bi-national position of Charles Villiers Stanford). Irish cultural revivalism had, until 1914, many overlaps with the arts and crafts movement in neighbouring England. There, too, we see a combination of social reformism and cultural nostalgia. Morris dancing, to give but one example, rustically retrieved and revived by Cecil Sharpe, was adopted by the feminist activist Mary Neal as a wholesome leisure-time activity for inner-city working women (Judge 1989). Design and applied arts provided an important meeting ground for aesthetes and radicals (and a congenial ambience for W. B. Yeats, future mastermind of the Irish currency design): Constance Gore-Booth Markievicz had studied at the Slade School of Art (like Lady Gregory's son Robert); Douglas Hyde attended William Morris's lectures in Dublin in 1886 (Daly 1974: 75-7); the Yeats sisters had their arts-and-crafts printing shop in south Co. Dublin, Elizabeth having been trained at the Women's Printing Society. This, too, meant that the political activism which piggybacked onto this cultural idealism could spill over between the two countries. The hunger strike as a means of political coercion was a joint invention of Irish nationalists and English suffragettes - in this case, Marion Wallace Dunlop, trained at the Slade School, fellow-activist of the vegetarian GoreBooth sisters, and impressed by Yeats's hunger-strike play At the King's Threshold (cf. Lennon 2007).

\section{LANGUAGE INTO, AND AFTER, SEPARATISM}

It would be wrong, then, to see Gaelic cultural revivalism a priori as the mere cultural outrider of political anti-British separatism: politicisation took over after 1910, and even then it was neither immediate nor absolute. Admittedly, the separatist turn between 1910 and 1915 was due to a large extent to an internal takeover by reactionary nativists, be they Catholic priests or hardcore Fenians; the drift towards an increasingly nativist anti-cosmopolitanism is documented in the admirable surveys by Philip O'Leary $(1994 ; 2004)$. But Irish cultural revivalism was also starved of its transnational oxygen by the national chauvinism that affected all other European countries besides Ireland, especially Britain, in 1914. The lack of English trade union support for the great Dublin strike and lockout of 1913 was an early warning, and started the drift of Connolly towards the Fenian Volunteers (for lack of alternative

${ }^{36}$ The Danish national songbook gained currency through the 'People's Academies' ('Folk High Schools', Folkehøjskole) movement; the German one involved the Commersbuch anthology used by student fraternities. Such institutional frames are absent in Ireland. 
anti-imperialists). The British acceptance of Orangist intransigence in Ulster was another turn of the screw. In a final blow, the cosmopolitan utopianism of the Edwardians was washed away in August 1914 in a tsunami of wartime jingoism, with even authors like A. A. Milne and H. G. Wells, and the ageing Thomas Hardy, being co-opted into anti-German war propaganda, while Rudyard Kipling and John Buchan gave the world ta-ra-ra-boom-de-ay with a vengeance (Sanders \& Taylor 1982; Buitenhuis 1987). The 'strange death of liberal England' and the war frenzy of 1914 rendered national chauvinism general all over Europe, including England, and served to push an isolated Irish cultural revivalism into the arms of the Fenians and the Irish Republican Brotherhood, and to give free rein to its more conservative-nationalist tendencies.

Whatever its causes, the separatist turn combined in equal measure a growing anti-cosmopolitanism and a growing political radicalisation. From 1911 onwards, the Gaelic League became increasingly entangled with Sinn Féin; in 1915, its IRB members gained full control of the organisation, prompting Douglas Hyde to resign as president. Some of these IRB members were cultural activists who had been radicalised in the preceding years; others were Fenian infiltrators. Following the Easter Rising, the British government banned the League as a seditious organisation. This briefly helped to boost the League's grassroots popularity: the number of branches, which had declined from 964 (1906) to 262 (1915), rose again to 312 (1917), 551 (1918) and 819 (1922). Its members were heavily represented in the First Dáil of 1919 and in the elite of the new Irish state that emerged afterwards; but in an independent Ireland, the League itself had the wind taken out of its sails. By 1924, the number of branches was down to 139 (Grote 1994: 77-8). Cultural revivalism was either a matter of state policy, or else etiolated in political antagonism during and after the Civil War.

And so the story of cultural politics in Ireland would seem to end with politics cannibalising culture; Pádraic Ó Conaire denouncing the cultural tokenism of the incoming nationalist politicos appears to have the last word ${ }^{37}$ The retreat of the language before the overwhelmingly superior forces of English continues, as maps of the Gaelic-speaking areas before and after 1922 show. Although given an official legal status as 'Gaeltacht' with the benefit of language-supporting policies, the erosion has continued unabated, both in terms of number of speakers, of Gaeltacht area surface,

\footnotetext{
${ }^{37} \mathrm{He}$ reiterated these strictures in 1922 when language legislation was debated in the new ('third') Dáil: 'Ach bíodh gach duine cinnte dearfa garb é an t-alt a bhaineann leis an teanga Ghaeilge an t-aon alt amháin nach gcuirfear ina aghaidh ... nach bhfuil san alt ach ornáideachas'; thus quoted in Ó hEallaithe (2005). ('Everyone is convinced that the paragraph on the Gaelic language will be the only noncontentious one [because] it is mere ornament.')
} 
and percentage of habitual Gaelophones in the area's total population. ${ }^{38}$

It would be too facile to blame language death on government inaction: the choice, which language to speak and in which language to raise one's children, is ultimately that of the speakers themselves (or else dependent on larger contextual pressures such as the need to emigrate). Also, the rage against tokenist inefficiency is largely a habitual by-product of the 'Sword of Light' myth. Languages much less intensely exposed to the proximity of English, and much more solidly entrenched in long-standing public institutions, are yielding before its overwhelming, globalising pressure; and the languages that have been successfully revived seem to owe that good fortune to a situation where the adoption of the language (Catalan, Finnish, Hebrew, Lithuanian) was part of a modernising stance against a backward empire, not a traditionalist stance against a modernising empire. ${ }^{39}$

There is indeed a tendency in post-1916 policy documents to de-prioritise and de-emphasise the preservation or revival of Gaelic. ${ }^{40}$ Nonetheless, its symbolic capital remained indispensable for the new state as 'the most irrefutable authenticating mark of the historic Irish nation on whose behalf a national state had been demanded' (Ó Tuathaigh 1991: 62-3). Accordingly, the Free State government in the 1920s had formulated, and assiduously pursued, four policy areas for the protection of the Irish language (Ó Riagáin 1997: 15):

1. a proactive fostering of the language as a medium of general communication in the Gaeltacht areas (which led, later in the century, to incentives for job creation as well as the establishment of successful Gaelic-language radio and television channels);

${ }^{38}$ Classic studies are Hindley (1990) and Ó Riain (1994). Also: Ó Huallacháin (1994) and Mac Giolla Chríost (2005).

${ }^{39}$ That opposition is also at work in the asymmetry between two closely connected language movements between 1850 and 1930, one (Catalan) highly successful as a progressive-liberal force in Spain, the other (Provençal/Occitan) hampered by its association with reactionary regionalism within France (Zantedeschi 2016). The Hebrew revival, a case sui generis, was uniquely successful because revived Hebrew, with a transregional familiarity from its liturgical usage, was a common lingua franca for the linguistically very disparate community of Zionist immigrants into Palestine. Cf. also Ó Laoire (1999).

${ }^{40}$ The Sinn Féin constitution of 1917 mentions language only as an educational priority alongside Irish history and 'Irish agricultural and manufacturing potentialities' (Macardle 1937: 914-15); the Saor Éire programme of 1931 only perfunctorily mentions, as a penultimate point, an aim 'To restore and foster the Gaelic Culture, Language and Pastimes' (Mitchell \& Ó Snodaigh 1985: 183-5). Significantly, Mitchell \& Ó Snodaigh's collection contains only two Gaelic-language documents: the 1919 Declaration of Independence (alongside its French and English versions) and a journalistic piece from An Glór (22 January 1944). 
2. a proactive tuition of Gaelic as a compulsory subject in primary and secondary education (and the fact that this notoriously failed to enthuse the long-suffering pupils must be blamed on the poor implementation of that policy, rather than on its conceptualisation);

3. a prioritisation of Gaelic in the offices of state as the state's national language;

4. a standardisation and modernisation of the language's dialect diffraction, vocabulary and spelling.

These policies were sensible, and they have in fact been reasonably successful, certainly in view of the language's exposure, at such very close quarters, to the globally overwhelming avalanche of an English-speaking modernity. The protection policies of the Irish state have ensured for Gaelic, if not a quantitative survival then a least a qualitative one: the Irish language enjoys at least a continuing symbolic status, and that is no small thing. Instead of bespeaking backward rusticism, Gaelic derives considerable prestige from being used by the highest officials of state in the most solemn circumstances; it is linked to the more highly educated and expertly literate sections of society, and in addition has in recent decades shed its reactionary, conformist reputation to become culturally 'cool'. A language-authenticated sense of tradition provides the cultural ambience for a variety of cultural practices which have been very successfully revived: dance, music, sports. While the language itself continues to be on life support, its protection and prestige-raising have ensured the successful revival of GAA sports (hurling and Gaelic football), traditional music and (to a slightly lesser extent) Irish dancing. These attract widespread active grassroots participation, and large, appreciative audiences and media exposure; and all of these pursuits had been placed on the agenda by the cultural revivalists of the decades 1890-1910. In addition, language nominalism has effectively managed to 'brand' the Irish public sphere as fundamentally Gaelic (much as Latin used to 'brand' the Catholic church). Political offices or institutions like Uachtarán, Taoiseach and Dáil; An Phost, Bus Éireann and Iarnród Éreann for the national postage, bus and railway services; the initials $R T E ́$ signifying the country's broadcasting corporation, Raidió Teilifis Éireann. Irish citizens are capable of singing along with the Gaelic-language national anthem, Amhrán na bhFiann; and no street or placename sign will omit the Gaelic name-form (Luimneach for Limerick, Fiachna Stiofáin for St. Stephens Green). And names like Sinéad, Nuala, Shane, Brendan, Roisín, and Máire are now perfectly normal and perfectly modern.

Thus Gaelic has been recycled, ironically, from the status of near-extinction directly to the status of what Michael Billig has called 'banal nationalism' (1995): the subliminal branding of the public sphere's background noise in a nation-affirming sense. Far from being a superficial or tokenist, ornamental veneer, this all-pervasive 
habitus of background-noise Gaelic (as in the Gaelic welcome formula opening in-flight announcements on Aer Lingus flights) is in fact a very forceful factor in public life.

The referential function of Gaelic in public communication is slight; but other Jakobsonian functions are quite robust: the phatic, the conative (on street signs and traffic signals) and indeed the poetic. Remarkably, Gaelic is still generating or obliquely inspiring a considerable and highly esteemed body of literature. This began in a delayed after-effect of the 1900 revival (which for a long time failed to produce serious literary work). A modernist school of literature tentatively emerged in the 1940s and 1950s. Authors like Flann O’Brien, Maíre Mhac an tSaoi and Mairtin Ó Direáin began to explore, in Gaelic, the problematics of modern life, and developed a subtle and ambitious literary tradition, restricted in readership but with great social and cultural allure, and for wider dissemination often relying on bilingual editions. ${ }^{41}$ Authors from Seán Ó Riordáin to Nuala Ní Dhomhnaill have equal standing alongside Samuel Beckett and Seamus Heaney in the country's literary pantheon. Also, starting with Seán Ó Tuama's landmark An Grá in Amhráin na nDaoine (1960), a body of literary criticism and historiography has sprung up which uses, with remarkable self-assurance, Gaelic as the language in which to present scholarly research - in the teeth of (and sometimes with its back turned to) the global position of English as the academic lingua franca.

This enduring cultural prestige is a remarkable survival from the contentious politicizations of the years after 1914. Although Sinn Féin's various successor parties still claim a preferential bond with Gaelic, the language has since the death of Éamon de Valera in 1975 (and despite the ongoing running sore of the Northern Irish 'troubles') been gradually dissociated from its old connotations of de-Anglicisation and anti-British political antagonism. This, too, is a generational development-and one which awaits closer investigation: how baby-boomers could maintain a commitment to Gaelic music, sports, dance, and its phatic/poetical functions, in spite of the old-school nationalism in which the language has, sometime around 1916, become entangled.

\section{Acknowledgements}

Thanks to Margaret Kelleher, Helen McGinley (Library of Trinity College Dublin), Ann Rigney, Eugene Roche (James Joyce Library, University College Dublin), and staff at the Long Room Hub, Trinity College Dublin: Sarah Barry, Caitriona Curtis, Eva Muhlhause.

${ }^{41}$ The process was first identified by O'Brien (1968) and has manifested itself in a lively tradition of linguistic crossover poetry between Gaelic and anglophone Irish poets bilingually anthologised. 


\section{REFERENCES}

Billig, Michael (1995), Banal Nationalism (London, Sage).

Bourdieu, Pierre (1979), La distinction: Critique sociale du jugement (Paris, Minuit).

Buitenhuis, Peter (1987), The Great War of Words: British, American and Canadian Propaganda and Fiction, 1914-1933 (Vancouver, BC, University of British Columbia Press).

Daly, Dominic (1974), The Young Douglas Hyde: The Dawn of the Irish Revolution and Renaissance, 1874-1893 (Dublin, Irish University Press).

Fitzgerald, Garret (1984), 'Estimates for Baronies of Minimum Level of Irish-speaking amongst Successive Decennial Cohorts: 1771-81 to 1861-71', Proceedings of the Royal Irish Academy 84.C.3: $117-55$.

Foster, Roy (2015), Vivid Faces: The Revolutionary Generation in Ireland 1890-1923 (Harmondsworth, Penguin).

Glandon, Virginia (1985), Arthur Griffith and the Advanced-Nationalist Press: Ireland 1900-1922 (New York, Peter Lang).

Golding, Maurice (1993), Pleasant the Scholar's Life: Irish Intellectuals and the Construction of the Nation State (London: Serif).

Gregory, Lady (1902) Cúchulain of Muirthemne (London, Alfred Nutt).

Grote, Georg (1994), Torn between Politics and Culture: The Gaelic League, 1893-1993 (Münster, Waxmann).

Hindley, Reg (1990), The Death of the Irish Language: A Qualified Obituary (London, Routledge).

Hogan, Robert \& Kilroy, James (eds) (1978-80), The Modern Irish Drama: A Documentary History vols. 1-3 (Dublin, Dolmen).

Holström, Kristen Gram (1967), Monodrama, Attitudes, Tableaux Vivants: Studies on Some Trends of Theatrical Fashion 1770-1815 (Almqvist \& Wiksell, Uppsala).

Hull, Eleanor (1898) The Cuchullin Saga (London, Alfred Nutt).

Hutchinson, John (1987), The Dynamics of Cultural Nationalism: The Gaelic Revival and the Creation of the Irish Nation State (London, Allen \& Unwin). http://dx.doi.org/10.4324/9780203245224

Hyde, Douglas (1986), Language, Lore and Lyrics: Essays and Lectures Breandán Ó Conaire (ed.) (Dublin, Irish Academic Press).

Jakobson, Roman (1960), 'Closing Statement: Linguistics and Poetics', in Style in Language, Thomas A. Sebeok (ed.) (Cambridge, MA, MIT Press), 350-376.

Joyce, James ([1914] 1956), 'The Dead', in Id., Dubliners (Harmondsworth, Penguin), 173-220.

Judge, Roy (1989), 'Mary Neal and the Espérance Morris', Folk Music Journal 5: 545-91.

Lajosi, Krisztina \& Stynen, Andreas (eds) (2015), Choral Societies and Nationalism in Europe (Leiden, Brill).

Leerssen, Joep (1996a), Mere Irish and Fíor-Ghael: Studies in the Idea of Irish Nationality, Its Development and Literary Expression Prior to the Nineteenth Century 2nd ed. (Cork, Cork University Press).

Leerssen, Joep (1996b), Remembrance and Imagination: Patterns in the Historical and Literary Representation of Ireland in the Nineteenth Century (Cork, Cork University Press).

Leerssen, Joep (2006), 'Nationalism and the Cultivation of Culture', Nations and Nationalism 12.4: 559-78. http://dx.doi.org/10.1111/j.1469-8129.2006.00253.x

Leerssen, Joep (2012), 'Memory Transfer', in Oona Frawley (ed.), Memory Ireland 2: Diaspora and Memory Practices (Syracuse, NY, Syracuse University Press), 137-48.

Leerssen, Joep (ed.) (2015). Encyclopedia of Romantic Nationalism in Europe (Amsterdam, Study Platform on Interlocking Nationalisms); online at http://romanticnationalism.net.

Lennon, Joseph (2007), 'Fasting for the Public: Irish and Indian Sources of Marion Wallace Dunlop's 1909 Hunger Strike', in Eoin Flannery \& Angus Mitchell (eds), Enemies of Empire: New Perspectives on Imperialism, Literature and History (Dublin, Four Courts), 19-39. 
Mac Aonghusa, Prionsias (1993), Ar son na Gaeilge: Conradh na Gaeilge, 1893-1993 (Baile Átha Cliath, Conradh na Gaeilge).

Macardle, Dorothy (1937), The Irish Republic: A Documented Chronicle of the Anglo-Irish Conflict and the Partitioning of Ireland, with a Detailed Account of the Period 1916-1923 (London, Gollancz).

Mac Giolla Chríost, Diarmuid (2005), The Irish Language in Ireland: From Goídel to Globalization (London, Routledge).

Mac Mathúna, Liam (2004), 'From Manuscripts to Street Signs via Séadna: The Gaelic League and the Changing Role of Literacy in Irish, 1875-1915', in Betsey Taylor FitzSimon \& James H. Murphy (eds), The Irish Revival Re-appraised (Dublin, Four Courts), 49-62.

Mantle, W. F., 'The Gaelic Athletic Association and Popular Culture, 1884-1934', in Oliver MacDonagh, W. F. Mantle \& Pauric Travers (eds), Irish Culture and Nationalism, 1750-1950 (Basingstoke, Macmillan), 104-121

Mecsnober, Tekla (2013), 'James Joyce and "Eastern Europe”: An Introduction', in R. Brandon Kershner \& Tekla Mecsnóber (eds), Joycean Unions: Post-millennial Essays from East to West (Amsterdam, Rodopi), 15-46. http://dx.doi.org/10.1163/9789401208826_005

Mitchell, Arthur \& Ó Snodaigh, Pádraig (eds) (1985), Irish Political Documents, 1916-1949 (Dublin, Irish Academic Press).

Moran, D. P. ([1905] 2006), The Philosophy of Irish Ireland repr. ed. intr. Patrick Maume; (Dublin, University College Dublin Press).

Morley, Vincent (2011), Ó Chéitinn go Raiftearaí: Mar a cumadh stair na hÉireann (Baile Átha Cliath, Coiscéim).

Morris, Catherine (2013), Alice Milligan and the Irish Cultural Revival (Dublin, Four Courts).

O’Brien, Frank (1968), Filiocht Gaeilge na linne seo: Staidéar criticiúil (Baile Átha Cliath, Clóchomhar).

Ó Glaisne, Risteárd (1994), Dúbhghlas de h-Íde (1860-1949) (1: Ceannrodai Cultúrtha, 1860-1919; Baile Átha Cliath: Conradh na Gaeilge).

Ó hÉallaithe, Donncha (2005), 'From Language Revival to Language Survival', in Ciarán Mac Murchaidh (ed.), Who Needs Irish? Reflections on the Importance of the Irish Language (Dublin, Veritas), 159-62.

Ó Huallacháin, Colman (1994), The Irish and Irish: A Sociolinguistic Analysis of the Relationship between a People and their Language (Baile Átha Cliath, Assisi Press).

Ó Laoire, Muiris (1999), Athbheochan na hEabhraise: Ceacht don Ghaeilge? (Baile Átha Cliath, Clóchomhar).

O'Leary, Philip (1994), The Prose Literature of the Gaelic Revival, 1881-1921: Ideology and Innovation (Philadlephia, PA, Pennsylvania State University Press).

O'Leary, Philip (2004), Gaelic Prose in the Irish Free State, 1922-1939. (Dublin, University College Dublin Press).

Ó Riagáin, Pádraig (1997), Language Policy and Social Reproduction: Ireland 1893-1993 (Oxford, Clarendon Press).

Ó Riain, Seán (1994), Pleanáil teanga in Éirinn, 1919-1985 (Baile Átha Cliath, Bord na Gaeilge).

Ó Súilleabháin, Donncha (1998), Athbheochán na Gaeilge: Cnuasach aistí (Baile Átha Cliath, Conradh na Gaeilge).

Ó Torna, Caitriona (2005), Cruthú na Gaeltachta 1893-1922 (Baile Átha Cliath, Cois Life).

Ó Tuama, Seán (1960) An Grá in Amhráin na nDaoine (Baile Átha Cliath, An Clochomhar).

Ó Tuathaigh, Gearóid (1991), 'The Irish-Ireland Idea', in Edna Longley (ed.), Culture in Ireland: Division or Diversity? (Belfast, Queen's University Belfast, Institute of Irish Studies).

Ó Tuathaigh, Gearóid (2008), 'The State and the Irish Language: An Historical Perspective', in Caoilfhionn Nic Phaidín \& Seán Ó Cearnaigh (eds), A New View of the Irish Language (Dublin, Cois Life), 26-42. 
Pašeta, Senia (2013), Irish Nationalist Women, 1900-1918 (Cambridge, Cambridge University Press). http://dx.doi.org/10.1017/CBO9781107256316

Rafroidi, Patrick (1983), 'Imagination and Revolution: The Cúchulain Myth', in Oliver MacDonagh, W. F. Mantle \& Pauric Travers (eds), Irish Culture and Nationalism, 1750-1950 (Basingstoke, Macmillan), 137-148. http://dx.doi.org/10.1007/978-1-349-17129-3_9

Rigney, Ann (2012), 'Transforming Memory and the European Project', New Literary History, 43: 607-28. http://dx.doi.org/10.1353/nlh.2012.0036

Ryan, Desmond (1939), The Sword of Light: From the Four Masters to Douglas Hyde, 1638-1938 (London, Barker).

Sanders, Michael \& Philip M. Taylor (1982), British Propaganda during the First World War, 1914-18 (Basingstoke, Macmillan). http://dx.doi.org/10.1007/978-1-349-05544-9

Sisson, Elaine (2005), Pearse's Patriots: St Enda's and the Cult of Boyhood (Cork, Cork Universoty Press).

Tierney, Michael (1980), Eoin MacNeill: Scholar and Man of Action, 1867-1845 Francis X. Martin (ed.) (Oxford, Clarendon Press).

Trotter, Mary (2001), Ireland's National Theaters: Political Performance and the Origins of the Irish Dramatic Movement (Syracuse, NY, Syracuse University Press).

Wolf, Nicholas M. (2014), An Irish-speaking Island: State, Religion, Community, and the Linguistic Landscape in Ireland, 1770-1870 (Madison, WI, University of Wisconsin Press).

Zantedeschi, Francesca (2016), 'The Antiquarians of the Nation: Archaeologists and Philologists in Nineteenth-century Roussillon', PhD thesis, Universitat Pompeu Fabra, Barcelona

Note on the author: Joep Leerssen is Professor of European Studies at the University of Amsterdam. His main fields of research are Irish Studies, imagology (the theory and history of cross-national stereotyping and national self-images) and the cultural history of national movements in Europe. He is editor of the Encyclopedia of Romantic Nationalism in Europe (printed ed. 2017, Amsterdam University Press).

J.T.Leerssen@uva.nl

To cite the article: Joep Leerssen (2016), 'Cúchulain in the General Post Office: Gaelic revival, Irish rising', Journal of the British Academy, 4: 137-168.

DOI $10.85871 / \mathrm{jba} / 004.137$

This article is licensed under a

Creative Commons Attribution-NonCommercial-NoDerivs 3.0 Unported License.

Journal of the British Academy (ISSN 2052-7217) is published by

The British Academy - the national academy for the humanities and social sciences.

10-11 Carlton House Terrace, London, SW1Y 5AH

www.britishacademy.ac.uk 